\title{
Peran Hakim dalam Menetapkan Wajib Nafkah Kepada Suami dalam Perkara Perceraian Di Pengadilan Agama Stabat (Nomor Perkara : 1696/Pdt.G/2019/PA Stb, tanggal 14 November 2019)
}

\author{
Muhammad Saleh ${ }^{1}$, Abdullah Sani Kurniadinata ${ }^{2}$, Tria Lestari $^{3}$ \\ ${ }^{1,2}$ Sekolah Tinggi Agama Islam Jam'iyah Mahmudiyah, Tanjung Pura \\ email: Muhammad_Saleh@staijm.ac.id,_Abdullah_Sani@staijm.ac.id
}

\begin{tabular}{l}
\hline INFO ARTIKEL \\
\hline Diterima \\
2 September 2019 \\
Direvisi \\
15 November 2019 \\
Disetujui \\
15 Desember 2019
\end{tabular}

Kata Kunci:

Peran Hakim; Wajib

Nafkah Suami;

Perceraian

\begin{abstract}
ABSTRAK
Tujuan penelitian ini untuk mengetahui aturan nafkah iddah menurut hukum Islam dan perundang-undangan di Indonesia dan untuk mengetahui cara penyelesaian nafkah iddah dan pertimbangan hakim Pengadilan Agama Stabat Kab. Langkat dalam mengabulkan permohonan nafkah iddah. Jenis penelitian adalah penelitian kualitatif dengan menggunakan teknik pengumpuluna data observasi, wawancara dan dokumentasi. Hasil kesimpulan dari penelitian ini bahwa didalam peraturan perundanganundangan aturan nafkah iddah telah diatur sesuai dengan aturan yang terdapat didalam agama Islam yakni pemberian nafkah iddah merupakan hal yang harus dipenuhi oleh suami pada saat terjadinya perceraian, dan apabila suami melalaikan kewajiban ini maka dapat diajukan gugatan di Pengadilan. Cara penyelesaian nafkah iddah dan hal-hal yang menjadi pertimbangan Hakim Pengadilan Agama Stabat Kab. Langkat dalam mengabulkan permohonan nafkah iddah adalah dengan berdasarkan pada surat gugatan mengenai pemberian nafkah iddah yang tercantum dalam gugatan pokok kemudian melakukan penilikan lebih lanjut mengenai nominal pemberian nafkah iddah, namun mengenai jumlah nominalnya pemberian nafkah iddah itu adalah sepenuhnya hasil kesepakatan dari kedua belah pihak. Pada pengambilan putusan, Hakim Pengadilan Agama Kabupaten Stabat dalam penyelesaian nafkah iddah mengacu kepada Undang-undang yaitu : a. Undang-undang No. 14 tahun 2006 tentang ketentuan-ketentuan pokok kekuasaan kehakiman. b. Undang-undang No. 1 tahun 2006 tentang perkawinan. c. Undang-undang No. 14 tahun 2005 tentang Mahkamah Agung. d. Undang-undang No. 7 tahun 2009 tentang Undang-undang Peradilan Agama.
\end{abstract}

\section{ABSTRACT}

The purpose of this study is to find out the rules of iddah living according to Islamic law and legislation in Indonesia and to find out how to settle the iddah living and the considerations of the judges of the Stabat Religious Court of Kab. Langkat in granting the request for iddah living. This type of research is a qualitative research using data collection techniques of observation, interviews and documentation. The conclusion of this study is that in the legislation, the rules of iddah living have been regulated in accordance with the rules contained in Islam, namely the provision of iddah living is 
something that must be fulfilled by the husband at the time of divorce, and if the husband neglects this obligation, a lawsuit can be filed. in the court. The method of completing the iddah living and matters that are considered by the Judge of the Stabat Regency Religious Court. The step in granting the application for iddah living is based on the letter of claim regarding the provision of iddah living contained in the main lawsuit and then conducting further surveillance regarding the nominal provision of iddah living, but regarding the nominal amount of the provision of iddah living, it is entirely the result of the agreement of both parties. In making a Keywords: decision, the Judge of the Stabat Regency Religious Court in the Judge's Role, settlement of iddah living refers to the law, namely: a. Law No. 14 of Husband's 2006 concerning the main provisions of the judicial power. b. Law Mandatory Support, No. 1 of 2006 concerning marriage. c. Law No. 14 of 2005 Divorce concerning the Supreme Court. d. Law No. 7 of 2009 concerning the Law on Religious Courts.

\section{Pendahuluan}

Perkawinan adalah salah satu asas pokok dalam kehidupan manusia yang paling utama dalam pergaulan hidup ditengah-tengah pergaulan masyarakat. Perkawinan merupakan suatu jalan yang penuh dengan kemuliaan untuk mengatur kehidupan manusia dalam melangsungkan rumah tangga dan sebagai usaha untuk meneruskan garis keturunan. Pada hakikatnya akad nikah adalah pertalian yang teguh dan kuat dalam kehidupan manusia. Bukan saja antara suami dengan istrinya melainkan antara dua keluarga. Baik dalam pergaulan antara suami dan istri saling kasih mengasihi juga berpindah kepada semua keluarga yang ada pada kedua belah pihak.

Perkawinan merupakan salah satu sunnatullah yang umumnya terjadi pada semua makhluk Allah Swt, baik pada mansuia, hewan maupun tumbuhtumbuhan. Semua yang diciptakan oleh Allah Swt berpasang-pasangan dan memiliki jodoh. Sebagaimana hal ini juga terjadi pada makhluk yang paling sempurna seperti manusia. Pada kenyataannya bahwa manusia tidak dapat hidup secara individualis melainkan manusia membutuhkan orang lain dan manusia disebut sebagai makhluk sosial Perkawinan merupakan suatu perbuatan hukum yang berlaku bagi setiap orang yang melakukannya. Indonesia sebagai negara hukum memiliki undang-undang tersendiri yang mengatur permasalahan perkawinan yaitu Undang-undang nomor 1 tahun 1974 tentang perkawinan. Undang-undang ini mengatur dan melindungi seluruh rakyat Indonesia yang melakukan perkawinan. Diberlakukannya undang-undang ini sebagai acuan untuk menyelesaikan permasalahan-permasalahan yang berkaitan dengan keluarga secara khusus. Selain undang-undang no 1 tahun 1974 tersebut pembahasan mengenai perkawinan juga diperinci dalam kompilasi hukum Islam.

Pada dasarnya perkawinan bertujuan untuk membentuk rumah tangga yang sakinah, mawaddah, warahmah sebagaimana dijelaskan dalam UU no. 1 tahun 1974 yaitu perkawinan bertujuan untuk membentuk keluarga (rumah tangga) yang bahagia dan kekal berdasarkan ketuhanan yang maha Esa. Oleh sebab itu suami dan istri perlu saling membantu dan melengkapi agar masing-masing dapat mengembangkan kepribadiannya untuk 
mencapai kesejahteraan spiritual dan material (Hadikusuma, 2019).

Adanya perkawinan tersebut maka keberadaan istri dan keturunan akan senantiasa terpelihara dengan baik, sebab jika tidak ada satu perkawinan, maka anak yang dilahirkan tidak diketahui siapa yang akan mengurusnya dan siapa yang akan bertanggung jawab dalam pemenuhan kebutuan anak tersebut. Perkawinan dapat dipandang sebagai kemaslahatan umum, sebab jika tidak ada perkawinan manusia akan mengikuti hawa nafsunya sebagaimana layaknya binatang. Maka, dengan sifat itu akan menimbulkan suatu perselisihan, bencana dan permusuhan antar sesama manusia yang mungkin juga dapat menimbulkan pembunuhan yang dahsyat (Saebani, 2018). Adapun tujuan perkawinan dalam Islam tidak hanya sekedar pada batas pemenuhan nafsu seksual saja. Melainkan, memiliki tujuantujuan penting yang berkaitan dengan aspek sosial, psikologis, dan agama (Azam., 2017).

Hakikat tujuan perkawinan yaitu untuk memenuhi tuntutan hajat dan tabiat kemanusiaan yang berhubungan antara laki-laki dan perempuan dalam rangka mewujudkan suatu keluarga yang bahagia dengan dasar cinta dan kasih sayang untuk memperoleh keturunan yang sah dalam masyarakat dengan mengikuti ketentuanketentuan dalam agama yang dianut oleh laki-laki dan perempuan yang melangsungkan perkawinan tersebut. Jadi, tujuan perkawinan dapat dirinci yaitu menghalalkan hubungan biologis untuk memenuhi hajat tabiat kemanusiaan, mewujudkan suatu keluarga dengan dasar rasa cinta kasih dan memperoleh keturunan yang sah (Syaifuddin, 2019).

Berjalan baik suatu kehidupan dalam ikatan perkawinan merupakan suatu tujuan perkawinan yang sangat diutamakan dalam agama Islam. Akad nikah diadakan untuk selamanya dan seterusnya agar suami dan istri bersama-sama dapat mewujudkan rumah tangga sebagai tempat berlindung, menikmati curahan kasih sayang dan dapat memelihara anak-anaknya sehingga mereka dapat tumbuh dengan baik. Begitu kuat dan kokohnya hubungan suami dan istri maka tidak sepantasnya apabila hubungan tersebut dirusak dan disepelekan. Setiap usaha untuk menyepelekan hubungan perkawinan dan melemahkannya sangat dibenci didalam agama Islam karena dianggap merusak kebaikan dan menghilangkan kemaslahatan antara suami dan istri. Oleh sebab itu, apabila terjadi perselisihan antara suami dan istri sebaiknya bisa diselesaikan hingga tidak terjadi perceraian. Karena pada dasarnya baik suami maupun istri tidak menginginkan hal itu terjadi

Pernikahan merupakan ikatan yang suci dan kuat serta mempunyai tujuan antara lain adalah persatuan, bukan perpisahan. Diperbolehkannya thalak hanya dalam keadaan tertentu saja dan apabila tidak ada jalan lain yang lebih baik selain perceraian tersebut. Menurut Sayyid Sabiq dalam kitab fiqih sunnah beliau menjelaskan bahwa "thalak diharamkan jika ada keperluan untuk itu menimbulkan mudharat, baik bagi suami maupun istri serta melenyapkan kemaslahatan antara suami dan istri itu tanpa ada alasan." (Sabiq, 2017) Oleh karena itu dalam pernikahan yang merupakan ikatan antara suami istri merupakan ikan paling suci dan kokoh dan tidak ada suatu dalil yang lebih jelas menunjukkan mengenai sifat yang paling suci dan agung tersebut melainkan dari Allah SWT.

Pada dasarnya pernikahan itu memiliki tujuan yang murni dan suci namun jika didalam pernikahan itu terjadi perselisihan antara pasangan suami dan 
istri maupaun pihak keluarga dari suami dan istri tentu akan membutuhkan jalan keluar yang baik bagi kedua belah pihak seperti pilihan untuk mengakhiri hubungan rumah tangga. Sehingga pada dasarnya pernikah itu tidak lagi mampu memuwujudkan cita-cita pernikahan yang pada awalnya merupakan tujuan dan citacita yang sangat diharapkan.

Seiring dengan legalnya hubungan pernikahan maka perceraian juga tidak bisa dipungkiri akan terjadi dalam kehidupan rumah tangga dalam lingkup masyarakat meskipun tidak pernah diinginkan dan direncanakan suatu perceraian tersebut. Tentu saja terjadinya perceraian itu pada saat dirasa bahwa tujuan pernikahan yaitu membentuk keluarga sakinah mawaddah warahmah tidak berhasil diantara kedua pasangan suami dan istri.

Sebagai respon atas realita kondisi darurat dan pemecahan masalah tersebut maka dapat diselesaikan antara suami dan istri dilakukan pemisahan secara baik-baik yaitu disebut dengan perceraian (talak). Islam membenarkan bahwa menempuh cara ini dianggap sebagai opsi atau jalan alternatif akan tetapi didalam agama Islam perceraian tidak pernah dianjurkan apabila didorong untuk melakukan perceraian tersebut. Hal terjadinya perceraian yang paling dirugikan adalah pihak istri yang khususnya tidak mempunyai penghasilan sendiri dan tempat tinggal sendiri. Disinilah tugas suami sebagai kepala rumah tangga untuk memenuhi kewajibannya atas istri dan anak-anaknya serta seluruh kebutuhan keluarga baik berupa nafkah, pakaian, rumah sebagai tempat tinggal dan kebutuhan lainnya. Namun, apabila suami tidak memberikan nafkah kepada istri dan anak-anaknya maka istri dapat menuntut kepada suami dan mengajukan gugatan ke pengadilan Agama.
Ulama fikih sepakat bahwa memberikan nafkah untuk istri adalah wajib dilihat dari perspektif hukum dan dampak dari akad nikah yang sah dan juga merupakan salah satu hak dari hak-hak yang dimiliki oleh istri dan suaminya sebagai konsekuensi akad nikah yang dianggap sah oleh syariat (Ya'qub, 2016). Dengan adanya ijab kabul pada saat dilangsungkannya pernikah maka secara langsung suami sudah menyetujui bahwa ia akan bersedia menanggung dan memberikan nafkah kepada istrinya baik nafkah lahir maupun batin. Terputusnya pernikahan antara suami dan istri menandakan bahwa terputusnya kewajiban suami memberikan nafkah kepada mantan istrinya. Namun, hukum memberikan nafkah tersebut tidak hanya berhenti disitu saja melainkan apabila setelah diajukan perkara perceraian tersebut ke pengadilan Agama dan diadili oleh hakim yang berwenang serta memutuskan bahwa mantan suami berkewajiban memberikan nafkah iddah kepada mantan istri maka hal tersebut pada dasarnya sudah sesuai dengan hukum agama Islam sebagaimana ditegaskan dalam Al quran pada surat al Baqarah ayat 241 :

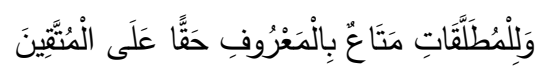

Artinya : Kepada wanita-wanita yang diceraikan (hendaklah diberikan oleh suaminya) mut'ah menurut yang ma'ruf, sebagai suatu kewajiban bagi orang-orang yang bertakwa. (Qs. Al-Baqarah : 241).

Berdasarkan penggalan ayat diatas yang dimaksud setiap wanita yang ditalak oleh suaminya berhak menerima nafkah iddah dan mut'ah (pemberian). Pemberian mut'ah oleh suami kepada istri yang telah ditalak adalah wajib tetapi harus disesuaikan dengan kemampuan si suami 
dan tidak boleh dipaksakan diluar batas kemampuan suami.

Meningkatnya perkara perceraian di Pengadilan Agama Stabat Kab. Langkat berdampak besar bagi hakim untuk dapat memberikan perlindungan kepada seorang istri yang telah ditalak oleh suaminya agar proses pemberian nafkah iddah dan mut'ah tidak mengalami lossis. Kepastian dalam menerima nafkah iddah dan mut'ah bagi seorang istri tersebut perlu dilakukan agar kehidupan istri yang telah ditalak tersebut masih dapat terjamin dengan baik.

Pengadilan agama adalah suatu lembaga atau institusi yang berwenang untuk menerima, memeriksa dan memutuskan suatu perkara perdata dalam lingkup agama islam. Pada dasarnya sikap Pengadilan Agama terhadap mantan suami yang tidak menjalankan kewajibannya pada masa iddah si isteri adalah tidak terlepas dari mantan istri itu sendiri apakah ia mengajukan perkaranya kepada Pengadilan Agama atau tidak. Andaikata si mantan istri tersebut tidak mengajukan keberatannya ke pengadilan agama maka sudah dianggap bahwa ianya telah merelakan jika si mantan suami tidak memenuhi kewajiban untuk memberikan nafkah iddah kepadanya. Berkenaan dengan pemberian nafkah setelah terjadinya perceraian merupakan suatu hal yang sangat penting, karena menyangkut kemaslahatan bagi mantan istri dan anak. Namun, ditengah-tengah masyarakat tidak sedikit ditemui kasus tentang istri yang dalam perceraian tidak mendapatkan nafkah dari mantan suami.

Tujuan penelitian ini untuk mengetahui aturan nafkah iddah menurut hukum Islam dan perundang-undangan di Indonesia dan untuk mengetahui cara penyelesaian nafkah iddah dan pertimbangan hakim Pengadilan Agama Stabat Kab. Langkat dalam mengabulkan permohonan nafkah iddah.
Kegunaan Penelitian di antaranya memberikan kontribusi berkaitan dengan hak dan kewajiban suami istri pada masa iddah mendapat perhatian dari instansi terkait terutama lembaga Pengadilan Agama. Karena banyak suami istri yang mengajukan gugatan perceraian tidak mengetahui hak dan kewajiban masingmasing. Maka harus diadakannya penyuluhan-penyuluhan kepada para pihak-pihak terkait tentang undang-undang perkawinan dan aturan-aturan lainnya. Dasar hukum putusan harus lebih dilengkapi. Hal ini untuk menghindari adanya rasa ketidakpuasan dari kedua belah pihak yang berperkara. Serta hakim jangan sampai dipengaruhi oleh keadaan psikologisnya dan senantiasa memperhatikan manfaat serta madharot dari pada putusan atau penetapan.

\section{Metode Penelitian}

Penelitian ini menggunakan metode penelitian kualitatif dengan pendekatan yuridis empiris yakni penelitian yang menekankan pada fakta-fakta yang didapatkan dari hasil penelitian yang didasarkan pada metode ilmiah yang tetap berpedoman pada teori hukum dan perundang-undangan yang berlaku. Pendekatan penelitian ini dengan pendekatan yuridis empiris yaitu untuk mendapatkan data primer (Soekanto, 2015). Lokasi dilaksanakannya penelitian ini di Kantor Pengadilan Agama di Stabat yang beralamat di Jl, Proklamasi Kec. Stabat Kab. Langkat.

Teknik pengumpuluna data dengan cara observasi, wawancara dan dokumentasi. Peneliti melakukan wawancara dengan para hakim di Pengadilan Agama Kabupaten Langkat dalam penentuan nafkah akibat adanya perceraian antara suami dan istri pengadilan agama. Sedangkan dalam 
rangka memahami perilaku dari segi bertindak dalam penelitian ini, maka peneliti melakukan kegiatan membaca (studi pustaka) dan menganalisis data dari putusan hakim dalam penentuan nafkah akibat perceraian tersebut.

Teknik Analisi data yang berbentuk informasi baik lisan maupun tulisan yang sifatnya bukan angka. Data dikelompokkan agar lebih mudah dalam menyaring mana data yang dibutuhkn atau tidak. Setelah dikelompokkan data tersebut penulis jabarkan dengan bentuk teks, agar lebih dimengerti, setelah itu penulis menarik kesimpulan dari data tersebut sehingga dapat menjawab masalah penelitian. (Patton, 2018). Teknik Analisis ini diharapkan memperoleh gambaran yang menyeluruh dan sistematis mengenai pandangan serta langkah hukum hakim dalam menentukan nafkah abkibat dari perceraian, bagaimana hakim melihat para pihak bercerai dimana hal tersebut memungkinkan untuk hakim menentukan nafkah.

\section{Hasil dan Pembahasan}

Pada dasarnya setiap orang yang melaksanakan perkawinan mempunyai tujuan atau cita-cita untuk selama-lamanya. Tetapi adakalanya suatu perkawinan karena sebab-sebab tertentu dapat berakibat putus atau tidak dapat dilanjutkan lagi, dan pada akhirnya perkawinan tersebut harus berakhir dengan perceraian antara suami istri. Undang-Undang Nomor 1 Tahun 1974 tentang Perkawinan menyebut secara umum mengenai putusnya hubungan perkawinan dalam tiga golongan seperti yang tercantum dalam Pasal 38 UndangUndang Nomor 1 Tahun 1974 tentang Perkawinan sebagai berikut.

1. Kematian yaitu putusnya perkawinan sebab kematian adalah dengan meninggalnya salah salah satu pihak (suami atau istri). Sejak saat meninggalnya salah satu pihak itulah perkawinan itu menjadi putus

2. Perceraian yaitu putusnya perkawinan karena perceraian adalah dengan pernyataan talak dari seorang suami.

3. Atas keputusan pengadilan yaitu putusnya perkawinan atas putusan pengadilan adalah putusnya perkawinan karena gugatan istri. Gugatan seorang istri yang melangsungkan perkawinan menurut agama Islam diajukan ke Pengadilan Agama, sedangkan gugatan seorang suami/istri yang melangsungkan perkawinan menurut agama dan kepercayaan bukan Islam gugatan diajukan ke Pengadilan Negeri.

Pada Undang-Undang Nomor 1 Tahun 1974 tentang Perkawinan, dicantumkanlah suatu asas bahwa tujuan perkawinan adalah untuk membentuk keluarga bahagia, kekal dan sejahtera, dengan demikian perceraian bukanlah suatu hal yang mudah untuk dilakukan menurut undang-undang ini. Untuk melakukan perceraian harus ada cukup alasan, bahwa antara suami istri itu tidak akan dapat hidup rukun sebagai suami istri. Perceraian hanya mungkin dengan salah satu alasan seperti disebutkan dalam Undang-Undang Perkawinan dan Peraturan Pelaksanaannya, yang harus dilakukan di depan Pengadilan. Bagi warga negara yang beragama Islam perceraian dilakukan di depan Pengadilan Agama.

Suatu perceraian secara hukum hanya dapat dilakukan di pengadilan karena pengadilan merupakan forum hukum yang dapat memberikan keputusan bagi para pihak terkait. Mengenai tata cara Perceraian, peraturan perundangundangan yang berlaku di Indonesia 
membagi dua klasifikasi cara berdasarkan agama atau kepercayaan yang dipeluk oleh pemohon Perceraian yaitu :

1. Tata cara perceraian bagi mereka yang melangsungkan perkawinan yang beragama Islam berdasarkan Pasal 14 sampai dengan Pasal 18 Peraturan Pemerintah Nomor 9 Tahun 1975 tentang Pelaksanaan Undang-Undang Nomor 1 Tahun 1974 tentang Perkawinan, serta Pasal 28 dan 29 Peraturan Menteri Agama Republik Indonesia Nomor 3 Tahun 1975. Pada kedua peraturan tersebut pada pokoknya adalah sebagai berikut :

a. Gugatan perceraian Gugatan yang diajukan oleh suami atau istri diajukan kepada pengadilan yang daerah hukumnya meliputi tempat kediaman tergugat. Permohonan ini harus dilengkapi dengan alasan-alasannya dan, meminta untuk diadakan sidang keperluan tersebut. Pengadilan Agama akan mempelajari isi surat permohonan dan dalam waktu selambat-lambatnya tiga puluh hari setelah diterimanya permohonan, pemohon akan dipanggil bersamasama dengan istrinya untuk didengar dan diminta penjelasan tentang segala sesuatu yang berkenaan dengan maksudnya untuk bercerai.

b. Setelah menerima penjelasan, Pengadilan Agama untuk pertama kalinya berusaha mendamaikan kembali kedua belah pihak yang akan bercerai dengan meminta bantuan Badan Penasehat Perkawinan dan Penyelesaian Perceraian yang biasa dikenal dengan BP4.

c. Dalam persidangan tentunya diwarnai dengan ketegangan ketegangan dari kedua pihak yang menginginkan dilaksanakan perceraian, sehingga sidang tidak harus selesai sekali bersidang tetapi mungkin juga berkali-kali. Pada setiap kali persidangan hakim juga berusaha mendamaikan lagi, sampai pengadilan berpendapat bahwa kedua pihak tidak dapat lagi didamaikan dan sudah cukup alasan talak. Lalu diadakan lagi sidang untuk mendengarkan dan menyaksikan pengucapan talak, di mana pada saat tersebut dihadiri juga oleh istrinya atau wakilnya. Sehabis mengikrarkan talak bekas suami kemudian menandatangani surat ikrar.

d. Selanjutnya Pengadilan membuat surat keterangan tentang terjadinya talak rangkap empat untuk keperluan: lembar pertama dilampiri surat ikrar dikirimkan kepada Pegawai Pencatat Nikah setempat Lembar kedua dan ketiga masing-masing diberikan kepada suami istri sedang lembar keempat untuk arsip.

e. Perceraian terjadi pada saat pengucapan talak di depan siding Pengadilan Agama tersebut di atas. Apabila talak sudah terjadi, maka kutipan akta nikah yang dipegang oleh masing-masing suami dan istri dicabut dan ditahan oleh Pengadilan Agama di tempat talak itu diikrarkan dan diberi catatan pada kolom yang tersedia bahwa pemilik sudah menjatuhkan/dijatuhi talak.

Adapun proses persidangannya yaitu pemeriksaan perkara cerai talak yang diatur dalam Bab IV, Bagian Kedua, Paragraf 2 Undang-Undang No. 7 Tahun 1989, hampir sama apa yang diatur dalam Bab V Peraturan Pemerintah No. 9 Tahun 
1975. Adapun mengenai pemeriksaan perceraian yang ditentukan dalam UndangUndang terdiri dari :

1. Cerai Talak

a. Suami mempunyai jalur tertentu dalam upaya menuntut upaya perceraian yaitu jalur suami melalui cerai talak.

b. Jalur hukum untuk suami ditempuh melalui gugat permohonan baik lisan atau tertulis ke Pengadilan Agama.

c. Dalam UU No. 7 Tahun 1989 ditentukan sifat gugat cerai talak adalah berupa permohonan yang identik dengan gugat volunter, namun dia berbeda dengan dari gugat volunter yang mumi. Gugat volunter yang mumi adalah sepihak, hanya pemohon saja. Orang yang disebut dalam permohonan sebagai objek, tidak berdiri sebagai subjek. Sedangkan dalam cerai talak istri sebagai pihak dan subjek perdata, malahan mempunyai hak untuk mengajukan banding dan kasasi. Jadi disini terlihat keunikan gugat cerai talak dibanding dengan gugat volunteer pada umumnya.

d. Suami sebagai pihak pemohon dan istri sebagai pihak termohon. Permohonan cerai talak diajukan kepada Pengadilan yang daerah hukumnya meliputi tempat kediaman termohon, kecuali apabila termohon dengan sengaja meninggalkan tempat kediaman yang ditentukan bersama tanpa ijin pemohon.

e. Dalam hal pemohon dan termohon bertempat tinggal $\mathrm{dl}$ luar negeri, maka permohonan diajukan kepada Pengadilan yang daerah hukumnya meliputi tempat mereka melangsungkan perkawinan

f. Pengadilan Agama dapat mengabulkan atau menolak permohonan tersebut dan terhadap keputusan tersebut dapat diminta upaya banding dan kasasi.

g. Pengadilan Agama yang bersangkutan mempelajari permohonan tersebut dalam waktu tiga puluh hari setelah itu memanggil pemohon dan termohon untuk dimintai penjelasan segala sesuatu yang berhubungan dengan maksud menjatuhkan talak.

h. Setelah Pengadilan Agama tidak berhasil menasehati atau mendamaikan kedua belah pihak dan ternyata cukup alasan untuk menjatuhkan talak serta yang bersangkutan tidak mungkin lagi hidup rukun dalam rumah tangga, Pengadilan Agama menjatuhkan keputusannya tentang ijin untuk mengikrarkan talak.

i. Setelah keputusan mempunyai keputusan hukum tetap, suami mengikrarkan talak di depan sidang Pengadilan Agama, dihadiri oleh istri atau kuasanya.

j. Bila suami tidak mengucapkan ikrar talak dalam waktu tempo enam bulan terhitung sejak keputusan Pengadilan Agama tentang ijin ikrar talak baginya mempunyai kekuatan hukum tetap, maka hak suami untuk diadakan mengikrarkan talak gugur dan ikatan perkawinan tetap utuh. 
k. Setelah penyaksian ikrar talak, Pengadilan Agama membuat penetapan tentang terjadinya talak rangkap empat yang merupakan bukti perceraian bagi bekas suami atau istri.

l. Helai pertama beserta surat ikrar talak dikirimkan kepada Pegawai pencatat nikah yang mewilayahi tempat tinggal suami untuk diadakan pencatatan helai kedua dan ketiga masing-masing diberikan kepada suami istri dan helai keempat disimpan oleh Pengadilan Agama.

2. Cerai Gugat.

a. Jalur untuk menuntut perceraian bagi istri adalah cerai gugat, yang pada dasarnya tats cara pemeriksaan tidak banyak berbeda dengan cerai talak. Misal persamaannya tentang hak yang berkenaan dengan pengiriman salinan dan pemberian akta cerai.

b. Yang bertindak sebagai penggugat adalah istri di tempat lain suami sebagai tergugat.

c. Gugatan diajukan kepada Pengadilan Agama meliputi tempat kediaman penggugat.

d. Seorang istri yang mengajukan gugatan perceraian dengan jalan khuluk, menyampaikan pemohonan kepada Pengadilan Agama yang mewilayahi tempat tinggalnya disertai alasanalasannya.

e. Dalam sidang tersebut Pengadilan Agama memberikan penjelasan tentang akibat khuluk dan memberikan nasehatnasehatnya. f. Setelah itu kedua belah pihak menyepakati besarnya iwald atau tebusan.

g. Jika sudah menyepakati besarnya iwald maka Pengadilan Agama memberikan penetapan tentang ijin bagi suami untuk mengikrarkan talaknya di depan sidang Pengadilan Agama.

Hukum Acara yang berlaku di pengadilan dalam perkara perceraian, secara garis besar mengikuti Hukum Acara Perdata. Namun terdapat kekhususan yang berlaku di dalam Hukum Acara di Pengadilan Agama, meliputi kewenangan relatif Pengadilan Agama, sifat persidangan, pemanggilan, pemeriksaan, pembuktian, dan biaya perkara, serta pelaksanaan putusan. Kekhususan Hukum Acara yang berlaku pada Pengadilan Agama di dasarkan pada Pasal 54 Undang-Undang Nomor 7 Tahun 1989 tentang Peradilan Agama jo Undang-Undang Nomor 3 Tahun 2006 tentang Perubahan Atas UndangUndang Nomor 7 Tahun 1989 tentang Peradilan Agama (Undang-Undang Peradilan Agama). Dengan demikian Hukum Acara yang berlaku pada Pengadilan Agama adalah Hukum Acara Perdata yang berlaku pada Pengadilan Umum, kecuali mengenai sejumlah hal lainnnya, yang diatur khusus, meliputi:

a. Bentuk dan proses perkara;

b.Kewenangan relatif Pengadilan Agama;

c. Pemanggilan pihak-pihak;

d.Pemeriksaan, pembuktian dan upaya damai;

e. Biaya Perkara;

f. Putusan hakim dan upaya hukum.

Pada Pengadilan Agama setidaknya secara umum ada 8 kali sidang, dalam proses perceraian, yakni :

a. Sidang pembacaan gugatan/perdamaian; 
b.Sidang jawaban;

c. Sidang replik;

d.Sidang duplik;

e. Sidang bukti-saksi Penggugat;

f. Sidang bukti-saksi Tergugat;

g. Sidang kesimpulan;

h.Sidang Putusan;

i. Ucap talaq (jika yg ajukan gugatan cerai adalah si suami)

Perceraian yang terjadi karena adanya talak dari suami terhadap istrinya, maka sesuai dengan ketentuan Pasal 41 (c) Undang-Undang Nomor 1 Tahun 1974 tentang Perkawinan, pengadilan dapat mewajibkan kepada mantan suami untuk memberikan biaya penghidupan dan atau menentukan sesuatu kewajiban kepada mantan istrinya. Pasal ini menentukan kewajiban dari mantan suami yang berupa mut'ah, nafkah iddah (bila istrinya tidak nusyus) dan nafkah untuk anak-anak. Nafkah iddah adalah pemberian nafkah dari (mantan) suami kepada (mantan) istrinya selama waktu tertentu (selama masa idah) setelah diucapkannya talak oleh si (mantan) suami. Nafkah iddah umumnya berupa uang. Sedangkan mut'ah adalah pemberian dari (mantan) suami kepada (mantan) istri sebagai akibat dari adanya perceraian, dimana istri telah dijatuhi talak. Mut'ah dapat berupa benda/perhiasan ataupun uang, umumnya besarnya biaya nafkah tersebut disesuaikan berdasarkan kesepakatan atau berdasarkan kemampuan si (mantan) suami. Mut'ah wajib diberikan oleh mantan suami dengan syarat belum ditetapkan mahar bagi istri ba'da al dukhul dan percerain atas kehendak suami.

Menurut historis iddah telah dikenal sejak zaman dahulu. Para ulama telah sepakat iddah itu hukumnya wajib bagi istri yang telah diceraikan. Iddah ialah masa tunggu atau tenggang waktu sesuai dengan jatuhnya thalak dari suami, dimana pada masa iddah ini suami boleh untuk merujuk kepada istrinya. Sehingga pada masa iddah ini si istri belum boleh untuk melangsungkan perkawinan dengan lakilaki lain. Pada masa iddah ini sebenarnya untuk meyakinkan kekosongan rahim si istri agar terhindar dari percampuran atau kekacauan nasab bagi anak yang dikandung.

Di samping itu untuk memikir kembali atau jalan yang mereka tempuh, apakah untuk merujuk kembali atau tetap meneruskan perceraian yang telah terjadi. Bagi istri yang telah diceraikan oleh suaminya, baik istri tersebut dicerai hidup dari pihak si suami atau si istri tersebut sedang mengandung atau tidak, maka si istri tersebut wajib untuk menjalani masa iddah sebagaimana tercantum dalam Kompilasi Hukum Islam Pasal 153 ayat yang menegaskan bahwa bagi seorang istri yang putus perkawinannya berlaku waktu tunggu atau iddah, kecuali qobla dukhul dan perkawinan putus bukan karena kematian suami. Iddah itu mempunyai beberapa unsur yaitu :

a. Suatu tenggang waktu tertentu

b.Wajib dijalani si bekas istri

c. Karena ditinggal mati oleh suaminya maupun diceraikan oleh suaminya

d.Keharaman untuk melakukan perkawinan selama masa iddah, untuk memperjelas pengertian tersebut di atas, bahwa iddah menurut pengertian hukum Islam ialah masa tunggu yang ditetapkan oleh hukum.

Oleh karena itu, setiap istri yang diceraikan suaminya diharuskan untuk menjalani masa iddah, yang lama waktunya ditetapkan menurut keadaan istri yang diceraikan atau suami yang menceraikannya, yakni apakah perceraian itu terjadi karena cerai proses pengadilan atau cerai karena kematian. Setelah 
terjadinya perceraian berdasarkan hukum perdata maupun hukum syara' si suami dibebankan untuk memberikan nafkah kepada pihak mantan istri. Dan apabila si suami tidak memberikannya, nafkah kehidupan (uang belanja) maka si istri dapat mengajukan masalah tersebut kepada pengadilan agama. Dalam masa iddah tersebut terdapat hak dan kewajiban suami-istri, yaitu: Hak Istri pada masa iddah :

a. Mendapatkan nafkah selama masa iddah

b. Mendapatkan perumahan selama masa iddah

c. Istri berhak memutuskan untuk rujuk kembali, sedangkan kewajiban istri adalah masa berkabung bila ia ditinggal mati suaminya.

Kewajiban suami pada masa

iddah istri

a. Suami wajib memberikan nafkah pada istri

b. Suami wajib memberikan perumahan pada istri

c. Suami berhak untuk merujuk kembali atau tidak.

Hak istri merupakan kewajiban suami untuk melaksanakan atau memenuhi hak-hak istri. Sedangkan kewajiban istri merupakan hak suami yang harus dijalankan oleh istri pada masa iddah. Pasal 4 (sub c) Undang-Undang No. 1 Tahun 1974 menyebutkan bahwa pengadilan agama dapat mewajibkan kepada bekas suami untuk memberikan biaya penghidupan dan atau menentukan suatu kewajiban bagi istri. Hal ini juga dipertegas dalam Kompilasi Hukum Islam Pasal 81 ayat (1 dan 2) yang menegaskan suami wajib menyediakan tempat tinggal bagi istri dan anak-anaknya atau bekas istrinya yang masih dalam masa iddah maka harus di beri haknya mendapatkan tempat tinggal dan biaya atau nafkah belanja sehari-hari.

Bila terjadi perselisihan mengenai jumlah, dapat dianjurkan dan diberikan pengarahan oleh pengadilan agama untuk diselesaikan secara musyawarah dan kekeluargaan. Akan tetapi bila tidak terjadi kesepakatan dalam penentuan jumlah maka pengadilan agama dapat menentukan jumlahnya yang disesuaikan dengan kemampuan suami dan tidak memberatkannya, dan sebaliknya diberikan pada saat setelah pembacaan sighat thalak di muka majelis hakim pengadilan agama melalaikan kewajibannya, atau sebab yang lainnya yaitu istri mengikhlaskan suami untuk tidak melaksanakan kewajibannya. Ini sesuai dengan Pasal 80 ayat (4) dan (7) Kompilasi Hukum Islam yang menyebutkan sesuai dengan penghasilannya suami menanggung biaya nafkah dari istri.

Pasal 136 ayat (2) KHI mengatur pengajuan permohonan istri atas nafkah, biaya pemeliharaan anak, dan harta perkawinan selama proses pemeriksaan berlangsung. Jelasnya, pada saat pemeriksaan perkara perceraian sedang berjalan, istri sebagai penggugat dapat mengajukan permohonan kepada hakim agar selama proses pemeriksaan perkara berlangsung lebih dulu ditetapkan nafkah, biaya pemeliharaan anak, dan harta perkawinan. Jadi sebelum pokok perkara diputus, hakim menetapkan lebih dulu berapa nafkah yang harus dibayar suami kepada istri setiap bulan. Berapa tiap bulan biaya pemeliharaan anak yang wajib dipenuhi suami serta kepada siapa diserahkan penjagaan harta bersama dan harta pribadi istri. Putusan yang seperti ini dapat dijatuhkan hakim mendahului putusan pokok perkara, dan putusan ini mempunyai kekuatan mengikat kepada kedua belah pihak sampai putusan pokok perkara mempunyai kekuatan hukum tetap. 
Pasal 24 ayat (2) PP No. 9 Tahun 1975 menyebutkan bahwa selama berlangsungnya gugatan perceraian, atas permohonan penggugat pengadilan dapat:

a.Menentukan nafkah yang ditanggung suami;

b. Menentukan hal-hal yang perlu untuk menjamin pemeliharaan anak;

c.Menentukan hal-hal yang perlu untuk menjamin terpeliharanya barang-barang menjadi hak bersama suami istri atau barangbarang yang rnenjadi hak suami atau barang-barang yang menjadi hak istri.

Menurut penulis hal tersebut di atas merupakan tindakan sementara dari pengadilan selama proses pemeriksaan perkara berlangsung diterapkan lebih dulu kepastian yang menjamin pembayaran natkah istri, biaya pemeliharaan dan pendidikan anak-anak. Karena jika tidak ditetapkan lebih, selama proses pemeriksaan perkara perceraian berlangsung terkadang prosesnya lama mulai dari tingkat pertama, tingkat banding dan kasasi, kemungkinan besar suami tidak mau memberi nafkah hidup istri atau suami tidak bersedia memberi biaya pemeliharaan kesehatan dan pendidikan terhadap anak.

\section{Kesimpulan}

Hasil Kesimpulan penelitian ini bahwa didalam peraturan perundanganundangan aturan nafkah iddah telah diatur sesuai dengan aturan yang terdapat didalam agama Islam yakni pemberian nafkah iddah merupakan hal yang harus dipenuhi oleh suami pada saat terjadinya perceraian, dan apabila suami melalaikan kewajiban ini maka dapat diajukan gugatan di Pengadilan. Cara penyelesaian nafkah iddah dan hal-hal yang menjadi pertimbangan Hakim Pengadilan Agama Stabat Kab. Langkat dalam mengabulkan permohonan nafkah iddah adalah dengan berdasarkan pada surat gugatan mengenai pemberian nafkah iddah yang tercantum dalam gugatan pokok kemudian melakukan penilikan lebih lanjut mengenai nominal pemberian nafkah iddah, namun mengenai jumlah nominalnya pemberian nafkah iddah itu adalah sepenuhnya hasil kesepakatan dari kedua belah pihak. Pada pengambilan putusan, Hakim Pengadilan Agama Kabupaten Stabat dalam penyelesaian nafkah iddah mengacu kepada Undang-undang yaitu : a. Undangundang No. 14 tahun 2006 tentang ketentuan-ketentuan pokok kekuasaan kehakiman. b. Undang-undang No. 1 tahun 2006 tentang perkawinan. c. Undangundang No. 14 tahun 2005 tentang Mahkamah Agung. d. Undang-undang No. 7 tahun 2009 tentang Undang-undang Peradilan Agama.

\section{Bibliografi}

Azam., A. A. (2017). Fiqih Munakahat. Jakarta: Amzah Publising.

Hadikusuma, H. (2019). Hukum Perkawinan Indonesia Menurut Perundangan, hukum adat, hukum agama. Bandung: CV. Mandar Maju.

Patton. (2018). Metode Penelitian Kualitatif . Jakarta: Rosdakarya.

Sabiq, S. (2017). Fiqih Sunnah, Penterjemah : Ghazali Effendi. Jakarta: Persada Press.

Saebani, B. A. (2018). Fiqih Munakat. Jakarta: Gaung Persada Press.

Soekanto, S. (2015). Penelitian hukum normatif,. Jakarta: Rajawali Press. 
Syaifuddin, M. (2019). Hukum Perceraian. Ya'qub, M. (2016). Nafkah Istri : Hukum Jakarta: Sinar Grafika. Menafkahi Istri dalam perspektif Islam. Jakarta: Darus Sunnah Press.

\section{Copyright holder :}

Muhammad Saleh, Abdullah Sani (2020).

First publication right :

Action Research Literate

This article is licensed under:

$$
\text { (c) } \underset{\mathrm{EY}}{\mathrm{i}} \mathrm{SA}_{\mathrm{SA}}
$$

